\title{
Systematic transitions in land use and land cover in a pre-Andean sub- watershed with high human intervention in the Araucania Region, Chile
}

\author{
Pablo Saavedra Briones ${ }^{1}$, and Alejandra Sepúlveda-Varas ${ }^{2}$ \\ 'Universidad Católica de Temuco, Escuela de Ciencias Ambientales. Casilla 15-D, Temuco, Chile. \\ ${ }^{2}$ Universidad Católica de Temuco, Núcleo de Investigación en Estudios Ambientales. Casilla 15-D, Temuco, \\ Chile.
}

\begin{abstract}
P. Saavedra Briones, and A. Sepúlveda-Varas. 2016. Systematic transitions in land use and land cover in a pre-Andean subwatershed with high human intervention in the Araucania Region, Chile. Cien. Inv. Agr. 43(3):396-407. Historical studies of land use changes help us to understand the current configuration of the landscape and identify the environmental and social impacts that are associated with these transformations. Several authors describe the transitions as a process of change that transforms the landscape system; for systematic transitions, these transitions are driven by stable and gradual processes. The objective of this study is to determine the trajectory and magnitude of land use and land cover (LULC) change for the 1994-2007 period in a pre-Andean sub-watershed with intensive human use in the central-southern zone of Chile and to analyze the most significant systematic transitions between land cover types. The results confirmed the reduction in the areas of agriculture and livestock and the increase of exotic plantations use on surfaces intended for agricultural use. The significant transitions were the conversion at a rate gain of 384 ha/year of "Farmlands" to "Exotic plantations", the abandonment at a loss rate of $119 \mathrm{ha} /$ year of "Perennial grasslands" to "Native vegetation", the degradation at a loss rate of 93 ha/year of "Native vegetation" to "Perennial grassland", and the revegetation at a rate gain of $60 \mathrm{ha} /$ year of "Exotic plantations" to "Native vegetation". The new patterns and trends in the use and intensity of land use reaffirmed the need for studies on the updated status of natural resources, particularly soil resources. This work, we believe, is a technical tool to support the sustainable management of a territory and the decision-making processes on land use.
\end{abstract}

Key words: Chile, land cover change, land use planning, LULC, systematic transitions.

\section{Introduction}

Evaluating the effects of land use and land cover (LULC) changes on terrestrial ecosystems depend

Received Mayo 26, 2016. Accepted November 14, 2016. Corresponding author: asepulve@uct.cl largely on the knowledge of past practices (NRC, 2001). Historical studies of LULC changes help researchers understand the current configuration of the landscape and identify the environmental and social impacts that are associated with these transformations (Andersen et al., 1996; Pan et al., 1999). Moreover, the modeling of scenarios 
can be used to link trends in vegetation cover changes with the underlying processes that are responsible for the changes in land cover. This connection helps researchers understand the mechanisms involved, generates predictions for future rates of change, identifies vulnerable sites, and contributes to the design of policies that can adequately respond to LULC changes (Braimoh, 2006; Henríquez et al., 2006; Pineda et al., 2009; Camacho et al., 2010). The regional analysis of land cover changes in heterogeneous landscapes can be masked by spatial variations caused by both bioclimatic and socioeconomic factors (Martínez-Fernández et al., 2015). According to Pontius et al. (2004), an appropriate methodology to analyze changes in land use is to obtain maps at two different times, examine the changes with a transition matrix to identify the most important transitions, and then investigate the processes that generate the transitions between land cover types. Often, researchers analyze this transition matrix at a very general level (e.g., CONAFCONAMA-BIRF, 1999; Aguayo et al., 2009; CONAF-CONAMA, 2009; CONAF, 2011) and draw conclusions about the dynamics of LULC change based only on the net change in the class totals between the years (Mertens and Lambin, 2000; Braimoh, 2006). However, the net change can dramatically underestimate the total change in the landscape (Mertens and Lambin, 2000). It is possible that the change occurs in such a manner that a given category changes its location between sampling times, but its magnitude stays the same (Pontius et al., 2004).

A common limitation of LULC change studies is that they consider change as one simple and irreversible conversion of one land cover type to another (Mertens and Lambin, 2000). Human societies coevolve with their surroundings, and the primarily nonlinear changes in LULC are related to social, physical, and biological changes at different organizational levels and occur through a multitude of transitions and trajectories between land covers that generate new complex patterns of land use (Braimoh, 2006; Carmona et al., 2010;
Carmona and Nahuelhual, 2012). A transition is a process of change that transforms the landscape system (Carmona and Nahuelhual, 2012), and transitions between land cover types are classified as random or systematic (Pontius et al., 2004; Braimoh, 2006). Random transitions are those that are influenced by involuntary processes or a single change; these transitions are characterized by abrupt changes and are often associated with the ability of an ecosystem to recover (Lambin et al., 2003; Pineda et al., 2009). The causes of such transitions tend to be factors that act unexpectedly, such as spontaneous population migration, internal land conflicts, and economic crises, among others (Lambin et al., 2003). Systematic transitions are driven by stable and gradual processes; these transitions are caused are permanent forces, such as natural population increases, the expansion of markets, and governmental changes in terms of the institutions that control access to resources (Lambin et al., 2003; Pineda et al., 2009; Carmona and Nahuelhual, 2012). Systematic transitions are identified when the difference between the observed rate and the expected value (based on gains or losses that are expected to randomly occur) are significantly different from zero (Braimoh, 2006; Pineda et al., 2009).

In this regard, human activities are the primary triggers of transformations in the landscape and land use changes associated with the processes of urban, industrial and productive growth (Yuan et al., 2005; Mas et al., 2009). In Chile, Nahuelhual et al. (2012) noted that the areas more vulnerable to future change in the southern regions of the country would be those located on soils that are marginal for agriculture (e.g., areas in the Andes and Coastal Ranges). These areas also concentrate high levels of rural poverty; therefore, recognizing these characteristics can be critical for designing conservation policies suited for each region (Martínez-Fernández et al., 2015). In this sense, the objective of this study is to determine the trajectory and magnitude of LULC change for the 1994-2007 period in a pre-Andean sub-watershed with intensive human use in the central-southern 
zone of Chile and to analyze the most significant systematic transitions between land cover types.

\section{Materials and methods}

Study area

The pre-Andean sub-watershed of the Quepe River is located between the latitudes $38^{\circ} 40^{\prime} \mathrm{S}$ and $39^{\circ} 00^{\prime} \mathrm{S}$ and the longitudes $71^{\circ} 45^{\prime} \mathrm{W}$ and $73^{\circ} 00^{\prime} \mathrm{W}$ in the Araucaria Region of Chile (Figure 1). The sub-watershed covers an area of 1.604 $\mathrm{km}^{2}$ in the regional Intermediate Depression; soils are mostly grouped in the Andisol order, which are derived from volcanic ash, with a high field capacity (40 to $60 \%$ at $33 \mathrm{kpa}$ ), high total porosity (60 to $80 \%$ ) and good internal drainage (CIREN, 2002). It is an exorheic sub-watershed with a pluvial regime and a rainy warm temperate climate with Mediterranean influence (Cfsb) and a reduced summer period of two months, according to the Köppen classification. The mean annual temperature is $12^{\circ} \mathrm{C}$, the mean relative humidity is $80 \%$, and the mean annual rainfall is $1.324 \mathrm{~mm}$ (Di Cqaastri and Hajek, 1976; PLADECO, 2010a; PLADECO, 2010b). Heading east to west, the fol- lowing three plant formations were observed: 1) Deciduous Forest of the Andes with Araucaria, 2) Mixed Deciduous Forest of the Andes and 3) South Deciduous Forest. The dominant economic activities are services, agriculture and forestry and construction.

Temporal analysis of the components of change between 1994 and 2007

The cartographic delimitation of the sub-watershed was determined by the General Water Directorate (DGA, 2004). Land covers were obtained from the following cartographic databases: the "Survey and Evaluation of the Native Vegetation Resources of Chile" (CONAF-CONAMA-BIRF, 1999) and its update (CONAF, 2011). Vector cartographic coverages were built based on photo interpretation of aerial photographs (1994) and orthophotos (2007) that had been orthorectified and corrected. Land covers were reviewed and homologated for the Geocentric Reference System for the Americas (i.e., the Universal Transverse Mercator (UTM) projection, which was based on Wideband Global SATCOM (WGS) 84 data for extended zone 18 South). The data were processed using ARCGIS

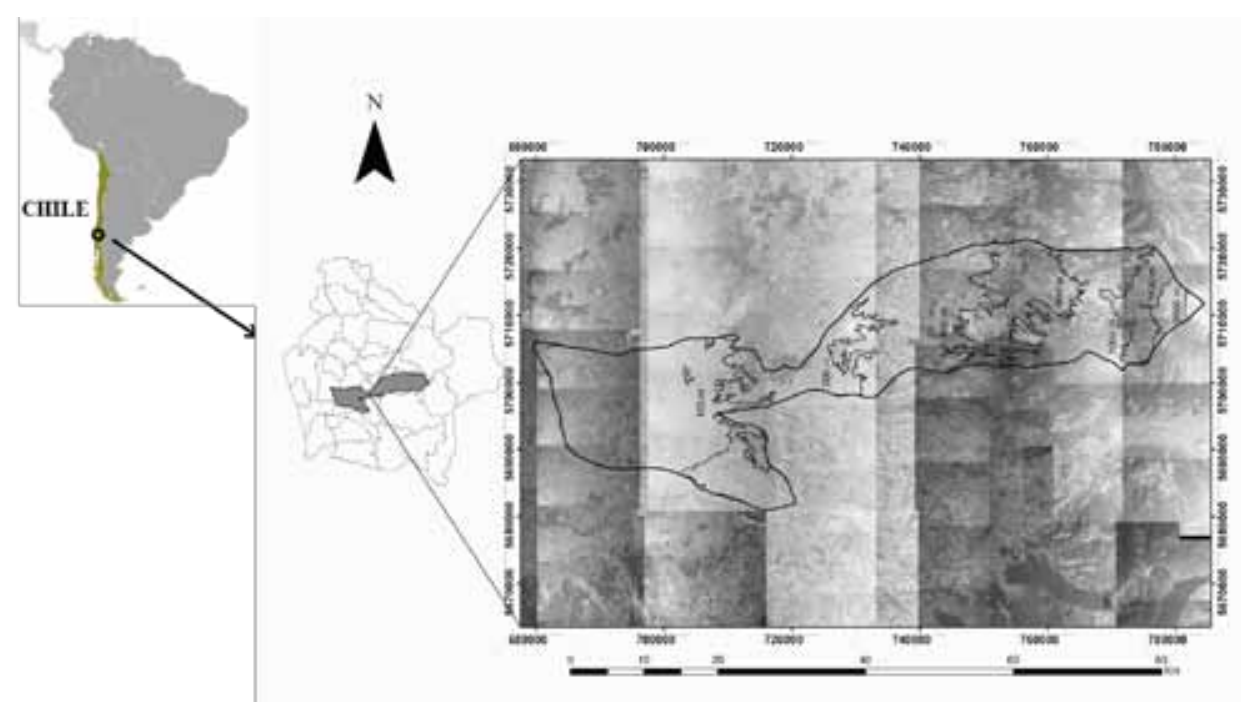

Figure 1. Study area in the Araucania Region, in the central-southern zone of Chile, at a sub-watershed of the Quepe River. 
9.3.1 software package (ESRI, USA). Meanwhile, cover classes were built based on a simplification and aggregation of the "General Vegetation Classification System" developed for the project "Survey and Evaluation of the Native Vegetation Resources of Chile" (CONAF-CONAMA-BIRF, 1999). The classes were as follows: (1) Native vegetation, (2) Farmlands, (3) Exotic plantations, (4) Perennial grasslands, and (5) Other coverage. All classes were based on the Charter of Land Occupation Montpellier.

Maps from 1994 (time 1) and 2007 (time 2) were analyzed using a change matrix constructed according to the method proposed by Pontius et al. (2004) and systematized following Braimoh (2006). In our study, the rows indicate the proportions of the five categories of cover in 2007, whereas the columns correspond to the proportions of the five categories of cover in 1994. The notation $\mathrm{C}_{i j}$ $(i \neq j)$ indicates the proportion of landscape that underwent a transition from category $i$ to category $j$ between 1994 and 2007. The components of the main diagonal, which are designated $c_{j j}$, indicate the proportion of cover of category $j$ that remained stable.

Based on the information in the matrix, the gross losses $\left(L_{i j}\right)$, gross gains $\left(G_{i j}\right)$, total change $\left(D_{j}\right)$, net change $\left(C_{j}\right)$, and swap $\left(S_{j}\right)$ between categories were calculated. The gross loss (Eq. 1) is the difference between the total time 1 column $\left(c_{j+}\right)$ and persistence $\left(c_{j j}\right)$. The gross gain (Eq. 2$)$ is the difference between the total time 2 row $\left(c_{+j}\right)$ and persistence $\left(c_{j j}\right)$. The swap (Eq. 3$)$ is defined as twice the minimum value of the gains or losses. The net change (Eq. 4) is the difference between gains and losses. The total change (Eq. 5) is considered the sum of the net change and swap or the sum of gains and losses (Pontius et al., 2004; López and Plata, 2009).

$$
\begin{aligned}
& L_{i j}=c_{j+}-c_{j j} \\
& G_{i j}=c_{+j}-c_{j j}
\end{aligned}
$$

$$
\begin{aligned}
& S_{j}=2 \times \min \left(c_{j+}-c_{j j}, c_{+j}-c_{j j}\right) \\
& C_{j}=\left(G_{i j}-L_{i j}\right) \\
& D_{j}=C_{j}+S_{j}
\end{aligned}
$$

\section{Identification of key signals of change}

To determine whether they were systematic or random in nature, the transitions between categories were analyzed according to the method proposed by Pontius et al. (2004), systemized by Braimoh (2006) and endorsed by López and Plata (2009), Pineda et al. (2009), and Carmona and Nahuelhual (2012). This method involves the construction of two systematic transition matrices based on the gains (Eq. 6) and losses (Eq. 7) that are expected to randomly occur.

$g_{i j}=\left(c_{+j}-c_{j j}\right) \times\left(\frac{c_{i+}}{1-c_{j+}}\right), i \neq j$

The difference $\left(d_{j}\right)$ between the observed values in the change matrix $(\mathrm{Vo})$ and the expected values $(\mathrm{Ve})$ under a process of random gain or random loss was determined and extracted from the systematic transition matrix based on the expected gains and losses, respectively. For more details regarding obtaining both matrices, see Pontius et al. (2004).

$l_{i j}=\left(c_{i+}-c_{i i}\right) \times\left(\frac{c_{+j}}{1-c_{+i}}\right), i \neq j$

To provide conclusive evidence for a key signal of landscape transformation, class $i$ must systematically win over class $j$, and class $j$ must systematically lose to class $i$ (Alo and Pontius, 2008).

\section{Indices of persistence and rate of change}

Additionally, the rates of change for each category were calculated using the formula proposed by the FAO (1996) and the indices of persistence proposed by Braimoh (2006). $P$ corresponds to the annual percentage of change of a single 
category (Eq. 8), whereas $S_{1}$ and $S_{2}$ correspond to the surfaces at time $t_{1}$ and $t_{2}$, respectively. Any quotient greater than 1 in Eqs. (9), (10), and (11) indicates a high tendency of a category to transition to another category rather than persist. $G_{p}$ corresponds to the index of gain-persistence, $l_{p}$ is the index of lost-persistence, and $n_{p}$ is the netpersistence index.

$$
\begin{aligned}
& p=\left(\frac{100}{t_{2}-t_{1}}\right) \times \ln \frac{S_{2}}{S_{1}} \\
& g_{p}=\frac{G_{i j}}{c_{i j}} \\
& I_{p}=\frac{L_{i j}}{c_{i j}} \\
& n_{p}=g_{p}-l_{p}
\end{aligned}
$$

\section{Results and discussion}

\section{Components of change}

Table 1 summarizes the values of the components of change analyzed for the sub-watershed. The category that had the highest gross loss was "Farmlands", with a 7.57\% decrease of surface at the landscape level; this category also experienced the greatest net change $(49 \%$ of the total change). The categories that experienced the highest gains corresponded to "Native vegetation" and "Exotic plantations" at 5.65 and 4.37\%, respectively. The land cover types that had the greatest surface swap dynamics corresponded to "Native vegetation" at 7.83\% and "Farmlands" at $5.18 \%$. Although "Exotic plantations" exhibited low swap, they constituted the category with the greatest annual change at $5.22 \%$ and the highest rate of gains-losses at $5.00 \%$ during the period of 1994-2007. This category also had the greatest value for the net positive change $(67 \%$ of the total change in the category; i.e., net change as part of the total change).

The swap represents changes in location between land covers, whereas the net change is associated with measurable irreversible change in the surface of one land cover to another (Braimoh, 2006; Alo and Pontius, 2008); having these two components of change allows the actual spatial dynamics of LULC change in the study area to be determined (Pontius et al., 2004). In this manner, it is possible to determine the total change in LULC between 1994 and 2007 and highlight the land cover types that exhibited the greatest variation (López and Plata, 2009). Thus, "Native vegetation", "Farmlands", and "Exotic plantations" were the land cover types that underwent the greatest spatial changes in the study area.

\section{Indices of persistence}

In the diagonal of Table 2, the percentages of persistence of each category during the period of 1994-2007 are listed. The total persistence of the study area reached $85.8 \%$, whereas the percentage of the surface that underwent a change in land cover was $14.2 \%$. "Farmlands" exhibited the highest persistence, maintaining a stable $56 \%$ of surface relative to 1994 , followed by "Native

\begin{tabular}{|c|c|c|c|c|c|c|}
\hline & Loss & Gain & Total change & Swap & $\begin{array}{c}\text { Rate of } \\
\text { gains-losses }\end{array}$ & Net change \\
\hline Native vegetation & 3.91 & 5.65 & 9.57 & 7.83 & 0.54 & 1.74 \\
\hline Farmlands & 7.57 & 2.59 & 10.17 & 5.18 & -0.63 & -4.98 \\
\hline Exotic plantations & 0.87 & 4.37 & 5.24 & 1.74 & 5.22 & 3.5 \\
\hline Perennial grassland & 1.47 & 1.11 & 2.58 & 2.23 & -0.46 & -0.36 \\
\hline Other coverage & 0.37 & 0.47 & 0.84 & 0.75 & 0.26 & 0.1 \\
\hline
\end{tabular}
vegetation" with $20 \%$ stability for the same period. The remaining categories exhibited a persistence

Table 1. Components of change (\%) of land cover of the study area during the period of 1994-2007. 
of less than $5 \%$ (based on the diagonal of persistence); this result highlights the need to analyze off-diagonal entries to avoid underestimating or overestimating changes. A change of $14.2 \%$ in the study area landscape represents a higher than normal change, considering that persistence often dominates the landscape in the majority of cases and is greater than $90 \%$ (Pontius et al., 2004).

Table 3 presents the results regarding the persistence of each category. The columns of $g_{p}$ and $l_{p}$ indicate that the categories exhibited a low tendency to transition from loss or gain to another category, with the exception of "Exotic plantations", which had the highest value of $g_{p}$ (1.60). This result indicates a high tendency for this land cover type to gain surface instead of remaining stable. A $g_{p}$ value of 1.6 means that the surface over which the category increased during the $1994-2007$ period is $160 \%$ greater than the surface over which this land cover type remained stable. Additionally, the $n_{p}$ value for "Exotic plantations" was greater than those of the other covers with a value of 1.28 ; this category tended to gain rather than lose as a function of its persistence. Thus, the net gains of "Exotic plantations" corresponded to $128 \%$ of the surface of its respective persistence.

Previous results confirm the advance of exotic forest surface in the study area at the expense of agricultural land, which is the same as the regional trend observed in the Araucanía (CONAF-CONAMA, 2009). This situation is primarily explained by the incentives granted by the State for the cultivation of exotic species and by the comparative advantages of the profitability of one item over another, e.g., livestock or agriculture (Aguayo et al., 2009; Carmona and Nahuelhual, 2012). Thus, "Exotic plantations" obtained greater gains than the "Farmlands" category, as indicated in Table 2. "Farmlands" experienced the greatest loss and total change of all the categories and had the lowest tendency to exhibit a transition of surface loss or gain to another category (Table 3 ). In this regard, López and Plata (2009) proposed that the enormous magnitude of persistence, compared with changes, could lead to erroneous conclusions about the dynamics of the territory. Thus, it becomes interesting to analyze the data outside the main diagonal because they help identify key and systematic patterns of change separate from any persistence level and land cover size (Pontius et al., 2004; Braimoh, 2006; Manandhar et al., 2010; Gutiérrez and Grau, 2014).

\section{Detection of key signals of change}

Table 4 presents the transitions based on the most significant gains between land covers. The most significant (positive) difference between the observed and expected value based on a process of random gains correspond to the transition from "Perennial grasslands" to "Native vegetation" at $0.51 \%$. Because the difference between $V o$ and $V e$ is far from zero, this transition qualifies as systematic; "Perennial grasslands" were replaced by "Native vegetation" 1.14 times faster than expected from a random process of gains for the latter category. Similarly, "Perennial grasslands" exhibited a $0.47 \%$ higher gain than "Native vegetation" compared with that expected for a process of random gain for "Perennial grasslands".

The transition from "Native vegetation" to "Farmlands" also qualified as a systematic transition; the difference of $0.30 \%$ indicates that the category of "Native vegetation" was systematically replaced to gain "Farmlands." At the same time, in the transition of "Farmlands" to "Exotic plantations", the latter category gained an additional $0.22 \%$ compared with what was expected from a random process. Also notable is the systematic transition of "Exotic plantations" to "Native vegetation"; the "Native vegetation" replaced plantations, gaining an additional $0.22 \%$ of surface at a rate 0.74 times faster than that expected from a process of random gain of native vegetation relative to plantations. The negative differences between $\mathrm{Vo}$ and $\mathrm{Ve}$ also indicate systematic transitions 
Table 2. Matrix of cover changes in the Quepe River sub-watershed. Each row corresponds to the total percentage of cover in 1994, and each column corresponds to the total percentage of cover in 2007.

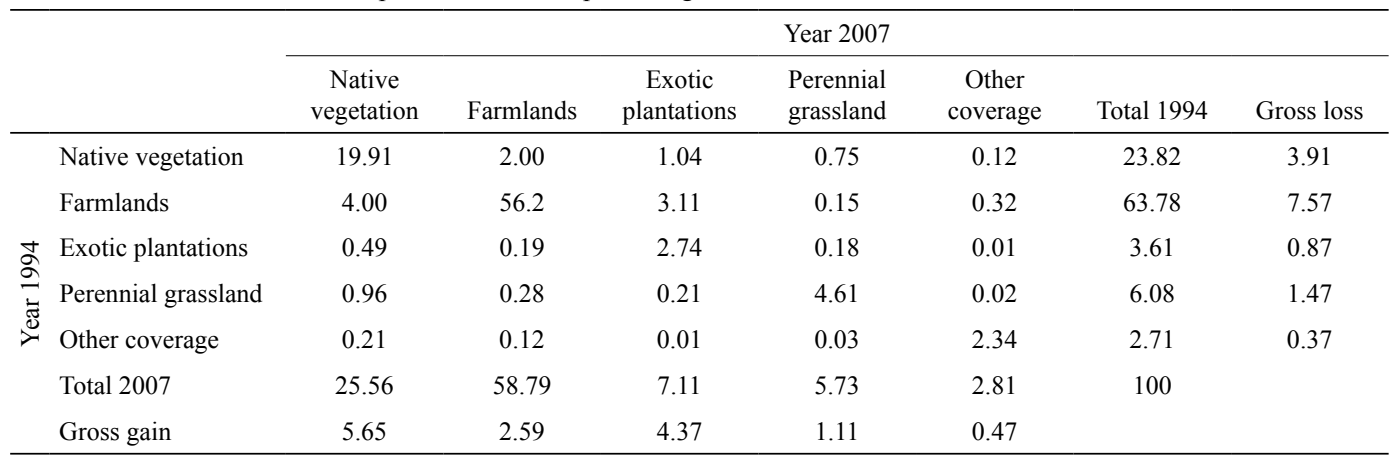

Table 3. Indices of gain-persistence $\left(g_{p}\right)$, loss-persistence $\left(l_{p}\right)$ and net-persistence $\left(n_{p}\right)$ change of each cover for the period of 1994-2007.

\begin{tabular}{lccc}
\hline & $\mathrm{g}_{\mathrm{p}}$ & $\mathrm{l}_{\mathrm{p}}$ & $\mathrm{n}_{\mathrm{p}}$ \\
\hline Native vegetation & 0.28 & 0.2 & 0.09 \\
Farmlands & 0.05 & 0.13 & -0.09 \\
Exotic plantations & 1.6 & 0.32 & 1.28 \\
Perennial grassland & 0.24 & 0.32 & -0.08 \\
Other coverage & 0.2 & 0.16 & 0.04 \\
\hline
\end{tabular}

Table 4. Primary systematic transitions based on gains between categories for the period of 1994-2007.

\begin{tabular}{|c|c|c|c|c|c|}
\hline Transition & Vo & $\mathrm{Ve}$ & $\mathrm{Vo}-\mathrm{Ve}$ & $\mathrm{Vo}-\mathrm{Ve} / \mathrm{Ve}$ & Interpretation \\
\hline $\begin{array}{l}\text { Native vegetation } 1994 \text { to Farmlands } \\
2007\end{array}$ & 2 & 1.7 & 0.3 & 0.17 & $\begin{array}{l}\text { When farmlands expand, they replace } \\
\text { the Native vegetation }\end{array}$ \\
\hline $\begin{array}{l}\text { Farmlands } 1994 \text { to native vegetation } \\
2007\end{array}$ & 4 & 4.73 & -0.73 & -0.16 & $\begin{array}{l}\text { When the native vegetation expands, } \\
\text { they do not replace farmlands }\end{array}$ \\
\hline $\begin{array}{l}\text { Native vegetation } 1994 \text { to exotic } \\
\text { plantations } 2007\end{array}$ & 1.04 & 1.08 & -0.04 & -0.03 & $\begin{array}{l}\text { When exotic plantations expand, they do } \\
\text { not replace the native vegetation }\end{array}$ \\
\hline $\begin{array}{l}\text { Farmlands } 1994 \text { to exotic plantations } \\
2007\end{array}$ & 3.11 & 2.89 & 0.22 & 0.07 & $\begin{array}{l}\text { When exotic plantations expand, they } \\
\text { replace farmlands }\end{array}$ \\
\hline $\begin{array}{l}\text { Perennial grassland } 1994 \text { to farmlands } \\
2007\end{array}$ & 0.28 & 0.44 & -0.15 & -0.35 & $\begin{array}{l}\text { When farmlands expand, they do not } \\
\text { replace perennial grasslands }\end{array}$ \\
\hline $\begin{array}{l}\text { Perennial grassland } 1994 \text { to native } \\
\text { vegetation } 2007\end{array}$ & 0.96 & 0.45 & 0.51 & 1.14 & $\begin{array}{l}\text { When the native vegetation expands, } \\
\text { they replace perennial grasslands }\end{array}$ \\
\hline $\begin{array}{l}\text { Native vegetation } 1994 \text { to Perennial } \\
\text { grasslands } 2007\end{array}$ & 0.75 & 0.28 & 0.47 & 1.66 & $\begin{array}{l}\text { When perennial grasslands expand, they } \\
\text { replace the native vegetation }\end{array}$ \\
\hline $\begin{array}{l}\text { Exotic plantations } 1994 \text { to Native } \\
\text { vegetation } 2007\end{array}$ & 0.49 & 0.27 & 0.22 & 0.74 & $\begin{array}{l}\text { When the native vegetation expands, } \\
\text { they replace exotic plantations }\end{array}$ \\
\hline
\end{tabular}

between categories. Thus, for the transition of "Farmlands" to "Native vegetation", the negative difference indicates that the latter category avoided the systematic gain of "Farmlands". The low value for the difference between "Native vegetation" and "Exotic plantations" indicated a random transition.
As observed from Table 5, the differences between $V o$ and $V e$ are greater than the differences based on gains. The highest difference corresponds to the transition from "Farmlands" to "Exotic plantations", which indicates that "Farmlands" lost an additional $1.8 \%$ surface than expected under a random loss process at a rate 1.38 
times faster than if the land had lost surface randomly. Transitions of "Native vegetation" to "Exotic plantations", "Perennial grassland" to "Native vegetation", "Native vegetation" to "Perennial grassland", and "Farmlands" to "Exotic plantations" exhibited positive differences, which confirmed the systematic character of surface transitions and involved the replacement of land cover that ceded land at an average loss rate that was 1.4 times faster than one would expect if the loss were random. Regarding transitions from "Native vegetation" to "Farmlands", "Farmlands" to "Native vegetation", and "Perennial grasslands" to "Farmlands", the negative differences denote that there was no replacement of the winning category for the losing category. Cultivated land did not replace "Native vegetation", and the tendency of cultivated land to avoid losing systematically to the latter category was high.

According to Alo and Pontius (2008), Braimoh (2006) and Manandhar et al. (2010), if category $i$ systematically gains from category $j$ and category $j$ systematically loses to category $i$, the results indicate a process of systematic transition from category $i$ to category $j$. Thus, by identifying systematic transitions based on gains and losses and verifying their simultaneous impact, key signals of LULC change in the study area are as follows (Figure 2): the conversion of $3.11 \%$ of "Farmlands" to "Exotic plantations" (a gain of 384 ha year ${ }^{-1}$ ), the abandonment of $0.96 \%$ of "Perennial grasslands" (a loss of 119 ha year ${ }^{-1}$ ) to "Native vegetation", the degradation of $0.75 \%$ of "Native vegetation" (a loss of 93 ha year") to "Perennial grasslands", and the revegetation of $0.49 \%$ of "Exotic plantations" to "Native vegetation" (a gain of 60 ha year ${ }^{-1}$ ).

Although the remaining transitions (Table 4 and 5) were also systematic, the lack of simultaneous incidences indicates that the results neither reveal the key signals of change in the landscape that this study seeks nor offers a clear vision regarding the covers that were subject to greater pressure (Stefanov et al., 2001; Cheng and Yang, 2008). Farmlands had the most extensive land cover in the study area and one of the greatest magnitudes of change (Table 1); these areas

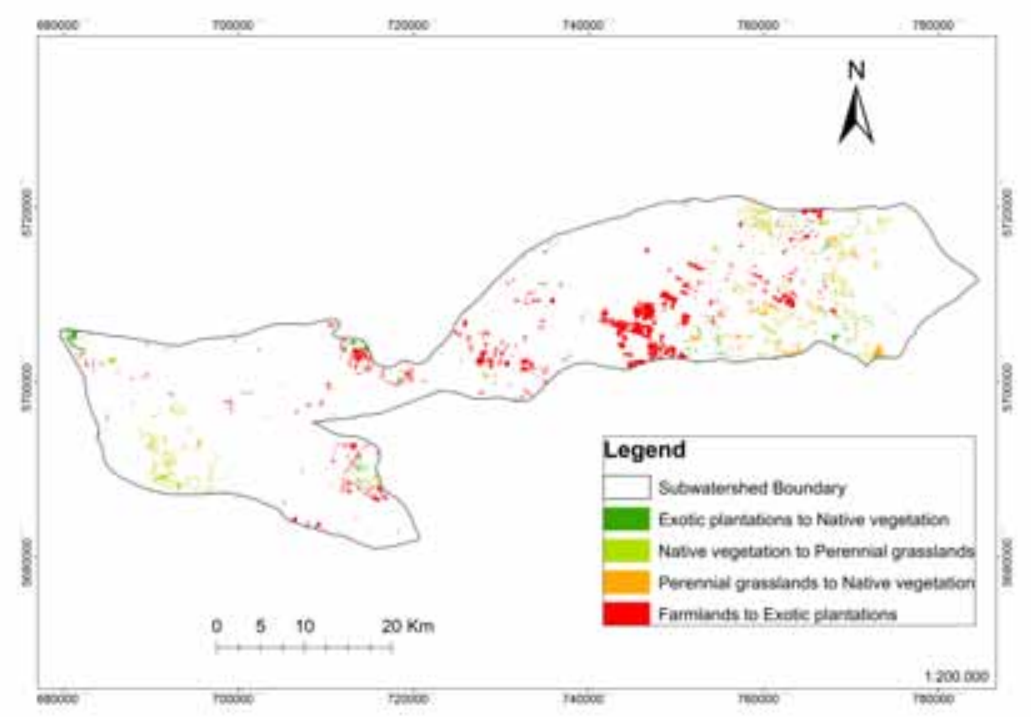

Figure 2. Key signals for land cover change in the sub-watershed of the Quepe River between 1994 and 2007. 
were primarily pressured by "Exotic plantations" because of the comparative economic advantages and capitalization from forestry activities during the past decade in the region (Aguayo et al., 2009; CONAF-CONAMA, 2009; Schulz et al., 2010; ICET, 2013). Braimoh (2006) noted that the decrease in agricultural surface was also due to the concentration of production in more productive lands, thereby resulting in the abandonment of unprofitable lands and followed by an eventual shift towards other products (INE, 2007). In fact, according to the Agriculture and Forestry Census of 1997, the "Farmland" surface underwent a contraction; however, the yields per hectare (qmt ha-1) for each type of traditional crop increased, and they even doubled in the intercensal period from 1997 to 2007 (INE-ODEPA, 2007; INE, 2007; INE, 2008; INE, 2011; ICET, 2013).

Meanwhile, the abandonment of "Perennial grasslands" to "Native vegetation" and the degradation of "Native vegetation" to "Perennial grassland" seemed to follow a pattern of abandonment of unproductive land and the preparation of new grazing land. In this respect, Díaz et al. (2011) noted that the recovery of native vegetation cover was associated with the abandonment of unprofitable lands, and both were due to industrializa- tion and urbanization of the area. Moreover, the revegetation of "Exotic plantations" to "Native vegetation" may be related to the harvest from lands that are home to exotic plantations, in which shrubland emerges as an alternative ecosystem until it is prepared for the next generation of exotic plantations.

The main conclusions indicate that the methodology used allowed for the identification of systematic transitions that occurred in the study area for the period between 1994 and 2007. The results confirmed a tendency towards the reduction of agriculture areas and livestock and increased exotic plantations use on surfaces intended for agricultural use. Specifically, the systematic transitions, and therefore the key signals of LULC change in the Quepe River sub-watershed, were as follows: (1) the conversion, at a rate gain of 384 ha year $^{-1}$, of $3.11 \%$ (4986 ha) of "Farmlands" to "Exotic plantations", (2) the abandonment, at a loss rate of 119 ha year $^{-1}$, of $0.96 \%$ (1545 ha) of "Perennial grasslands" to "Native vegetation", (3) the degradation, at a loss rate of 93 ha year 1 , of $0.75 \%$ (1207 ha) of "Native vegetation" to "Perennial grassland", and (4) the revegetation, at a rate gain of 60 ha year- 1 , of $0.49 \%$ (778 ha) of "Exotic plantations" to "Native vegetation" (which had the weakest signal). Therefore, the

Table 5. Primary systematic transitions based on losses between categories for the period of 1994-2007.

\begin{tabular}{|c|c|c|c|c|c|}
\hline Transition & Vo & $V e$ & $V o-V e$ & $\mathrm{Vo}-\mathrm{Ve} / \mathrm{Ve}$ & Interpretation \\
\hline $\begin{array}{l}\text { Native vegetation } 1994 \text { to farmlands } \\
2007\end{array}$ & 2 & 3.09 & -1.09 & -0.35 & $\begin{array}{l}\text { When the native vegetation is lost, it is } \\
\text { not replaced by farmlands }\end{array}$ \\
\hline $\begin{array}{l}\text { Farmlands } 1994 \text { to native vegetation } \\
2007\end{array}$ & 4 & 4.7 & -0.7 & -0.15 & $\begin{array}{l}\text { When farmlands are lost, it is not } \\
\text { replaced by the native vegetation }\end{array}$ \\
\hline $\begin{array}{l}\text { Native vegetation } 1994 \text { to exotic } \\
\text { plantations } 2007\end{array}$ & 1.04 & 0.37 & 0.67 & 1.79 & $\begin{array}{l}\text { When the native vegetation is lost, it is } \\
\text { replaced by exotic plantations }\end{array}$ \\
\hline $\begin{array}{l}\text { Farmlands } 1994 \text { to exotic plantations } \\
2007\end{array}$ & 3.11 & 1.31 & 1.8 & 1.38 & $\begin{array}{l}\text { When farmlands are lost, they are } \\
\text { replaced by exotic plantations }\end{array}$ \\
\hline $\begin{array}{l}\text { Perennial grassland } 1994 \text { to farmlands } \\
2007\end{array}$ & 0.28 & 0.92 & -0.64 & -0.69 & $\begin{array}{l}\text { When perennial grasslands are lost, } \\
\text { they are not replaced by farmlands }\end{array}$ \\
\hline $\begin{array}{l}\text { Perennial grassland } 1994 \text { to native } \\
\text { vegetation } 2007\end{array}$ & 0.96 & 0.4 & 0.57 & 1.42 & $\begin{array}{l}\text { When perennial grasslands are lost, they } \\
\text { are replaced by the native vegetation }\end{array}$ \\
\hline $\begin{array}{l}\text { Native vegetation } 1994 \text { to Perennial } \\
\text { grassland } 2007\end{array}$ & 0.75 & 0.3 & 0.45 & 1.5 & $\begin{array}{l}\text { When the native vegetation is lost, it is } \\
\text { replaced by perennial grasslands }\end{array}$ \\
\hline $\begin{array}{l}\text { Exotic plantations } 1994 \text { to native } \\
\text { vegetation } 2007\end{array}$ & 0.49 & 0.24 & 0.25 & 1.03 & $\begin{array}{l}\text { When exotic plantations are lost, they } \\
\text { are replaced by the native vegetation }\end{array}$ \\
\hline
\end{tabular}


change in land use is linked to the socioeconomic aspects of the study area; this shows the importance of identifying the impact of production decisions on the structure and function of the agroecosystem, thus allowing for the development of public policies that adequately respond to trends in land use.

\section{Acknowledgements}

The authors thank the General Office of Research and Post-graduate Study, Universidad Católica de Temuco (Chile), project DGIP 2011-3-09. We also appreciate the contribution of Dr. Carlos Esse H. and Biol. Rodrigo Santander M. in GIS tools.

\title{
Resumen
}

\begin{abstract}
P. Saavedra Briones y A. Sepúlveda-Varas. 2016. Transiciones sistemáticas en cobertura y uso del suelo para sub-cuenca pre andina de alta intervención antrópica, Región de la Araucanía, Chile. Cien. Inv. Agr. 43(3):396-407. Estudios de los cambios en el uso de la tierra permiten comprender la configuración actual del paisaje e identificar los impactos ambientales y sociales que se asocian a estas transformaciones. Diversos autores describen "transiciones" como un proceso de cambio que transforma el paisaje, donde las "transiciones sistemáticas" son impulsadas por procesos estables y graduales. El objetivo de este estudio es determinar la trayectoria y magnitud del cambio de cobertura y uso de la tierra para el periodo 1994-2007 en sub-cuenca pre-andina de uso intensivo en el centro-sur de Chile y analizar las transiciones sistemáticas más significativas entre tipos de cobertura. Los resultados obtenidos confirman la reducción de áreas destinadas a agricultura-ganadería y el aumento de áreas de uso forestal: conversión, a una tasa de 384 ha año-1 de "Cultivos y pastizales naturales" a "Plantaciones forestales"; abandono, a una tasa de pérdida de 119 ha año ${ }^{-1}$, de "Praderas perennes" a "Bosque nativo y matorrales"; degradación, a una tasa de pérdida de 93 ha/año, de "Bosque nativo y matorrales" a "Pastizal perenne"; y revegetación, a una tasa de ganancia de 60 ha año-1, de "Plantaciones forestales" a "Bosques y matorrales nativos". Así, debido a los nuevos patrones y tendencias en el uso de la tierra se reafirma la necesidad de contar con estudios sobre el estado actualizado de los recursos naturales, en particular el recurso suelo. Este trabajo, representa una herramienta de apoyo tanto para la gestión sostenible de un territorio como para la toma de decisiones sobre el uso de la tierra.
\end{abstract}

Palabras clave: Cambios cobertura de la tierra, Chile, LULC, planificación uso de la tierra, transiciones sistemáticas.

\section{References}

Aguayo, M., A. Pauchard, G. Azócar, and O. Parra. 2009. Cambio del uso del suelo en el centro sur de Chile a fines del siglo XX: entendiendo la dinámica espacial y temporal del paisaje. Revista Chilena de Historia Natural 82:361-74.

Andersen, O., T. Crow, S. Lietz, and F. Stearns. 1996. Transformation of a landscape in the upper midwest, USA: The history of the lower St Croix River valley, 1830 to present. Landscape and Urban Planning 35:247-267.
Alo, C., and R. Pontius. 2008. Identifying systematic land-cover transitions using remote sensing and GIS: the fate of forests inside and outside protected areas of Southwestern Ghana. Environment and Planning: Planning and Design 35(2):280-295.

Braimoh, AK. 2006. Random and systematic landcover transitions in northern Ghana. Agriculture, Ecosystems \& Environment 113(1-4):254-263.

Camacho, M., E. Molero, and M. Paegelow. 2010. Modelos geomáticos aplicados a la simulación de cambios de usos del suelo. Evaluación del poten- 
cial de cambio. p. 658-678. In: Ojeda, J., M. Pita and I. Vallejo (eds.). Tecnologías de la Información Geográfica: La Información Geográfica al servicio de los ciudadanos. Secretariado de Publicaciones de la Universidad de Sevilla. Sevilla, España.

Carmona, A., L. Nahuelhual, C. Echeverría, and A. Báez. 2010. Linking farming systems to landscape change: an empirical and spatially explicit study in southern Chile. Agriculture, Ecosystems \& Environment 139(1-2):40-50.

Carmona, A., and L. Nahuelhual. 2012. Combining land transitions and trajectories in assessing forest cover change. Applied Geography 32:904-15.

Chen, LY., and H.C.H. Yang. 2008. Scenario simulation and forecast of land use/cover in northern China. Chines Science Bulletin 53:1401-1412.

CIREN. 2002. Descripciones de suelos: materiales y símbolos, estudio agrológico IX Región. Centro de Información de Recursos Naturales. 360 pp.

CONAF-CONAMA-BIRF. 1999. Catastro y Evaluación de Recursos Vegetacionales Nativos de Chile: Informe Nacional Con Variables Ambientales. Ministerio de Agricultura, Chile. 89 pp.

CONAF-CONAMA. 2009. Catastro de uso de suelo y vegetación: monitoreo y actualización región de La Araucanía. Ministerio de Agricultura, Chile. 29 pp.

CONAF. 2011. Catastro de los recursos vegetacionales nativos de Chile: monitoreo de cambios y actualizaciones período 1997-2011. Ministerio de Agricultura, Chile. 28 pp.

DGA. 2004. Análisis de disponibilidad recursos hídricos superficiales cuenca río Quepe, Informe Técnico. Departamento de Administración de Recursos hídricos. S.D.T N ${ }^{\circ} 175$. Ministerio de Obras Públicas. 90 pp.

Díaz, G., L. Nahuelhual, C. Echeverría, and S. Marín. 2011. Drivers of land abandonment in Southern Chile and implications for landscape planning. Landscape and Urban Planning 99(3-4):207-217.

Di Castri, F., and E. Hajek. 1976. Bioclimatología de Chile. Ediciones Universidad Católica de Chile, Santiago, Chile. 128 pp.

FAO. 1996. Forest resources assessment 1990. Survey of tropical forest cover and study change process. Rome $\mathrm{N}^{\circ} 26.152 \mathrm{pp}$.
Gutiérrez, J., and R. Grau. 2014. Assessment of swaps and persistence in land cover changes in a subtropical periurban region, NW Argentina. Landscape and Urban Planning 127:83-93.

Henríquez, C., G. Azócar, and M. Aguayo. 2006. Cambio de uso del suelo y escorrentía superficial: aplicación de un modelo de simulación espacial en Los Ángeles, VIII región Del Biobío, Chile. Revista de Geografía Norte Grande 36:61-74.

ICET. 2013. Sistema de consulta estadístico territorial: censo agropecuario. Oficina de estudios y Políticas Agrarias. Available online at: http://icet. odepa.cl/ (Website accessed July, 2015).

INE. 2007. Cambios estructurales en la agricultura chilena: análisis intercensal 1976-1997-2007. 72 pp. Available online at: http://www.ine.cl/canales/ chile_estadistico/censos_agropecuarios/censos_ agropecuarios.php (Website accessed July, 2015).

INE. 2008. Enfoque estadístico: VII censo agropecuario y forestal. Instituto Nacional de Estadísticas. $12 \mathrm{pp}$. Available online at: http://www.ine.cl/ canales/sala_prensa/noticias/2007/marzo/files/ septimo_censo_agropecuario_pdf.pdf (Website accessed July, 2015).

INE. 2011. Censo Agropecuario y forestal 2007, resultados por comuna. Available online at: http:// www.ine.cl/canales/chile_estadistico/censos_agropecuarios/censo_agropecuario_07_comunas. php (Website accessed May, 2015).

INE-ODEPA. 2007. Enfoque estadístico: VII censo nacional agropecuario y forestal. Ministerio de Agricultura. 8 pp. Available online at: http:// www.ine.cl/canales/sala_prensa/noticias/2007/ noviembre/pdf/resultadoscenso_pags131107.pdf (Website accessed May, 2015).

Lambin, E., H. Geist, and E. Lepers. 2003. Dynamics of land use and cover change in tropical regions. Annual Review of Environment and Resources 28:205-241.

López, V., and W. Plata. 2009. Análisis de los cambios de suelo derivados de la expansión urbana de la zona metropolitana de la Ciudad de México, 19902000. Investigaciones Geográficas 68:85-101.

Manandhar, R., I. Odeh, and R. Pontius. 2010. Analysis of twenty years of categorical land transitions in the Lower Hunter of New South Wales, 
Australia. Agriculture, Ecosystems \& Environment 135:336-346.

Martínez-Fernández, J., P. Ruiz-Benito, and M. Zavala. 2015. Recent land cover changes in Spain across biogeographical regions and protection levels: Implications for conservation policies. Land Use Policy 44: 62-75.

Mas, JF., A. Velázquez, and S. Couturier. 2009. La evaluación de los cambio de cobertura/uso del suelo en la República Mexicana. Investigación Ambiental 1:23-39.

Mertens, B., and E. Lambin. 2000. Land-coverchange trajectories in southern Cameroon. Annals of the Association of American Geographers. 90:467-494.

Nahuelhual, L., A. Carmona, A. Lara, C. Echeverría and M. González. 2012. Land-cover change to forest plantations: Proximate causes and implications for the landscape in south-central Chile. Landscape and urban planning. 107: 12-20.

NRC. 2001. Grand challenges in environmental sciences. Committee on Grand Challenges in Environmental Sciences. National Research Council, National Academy Press, Washington DC, USA. 106 pp.

Pan, D., G. Domon, S. de Blois, and A. Bouchard. 1999. Temporal (1958-1993) and spatial patterns of land use changes in Haut-Saint-Laurent (Quebec, Canada) and their relation to landscape physical attributes. Landscape Ecology 14:35-52.
Pineda, N., J. Bosque-Sendra, M. Delgado, and W. Plata. 2009. Análisis de cambio del uso del suelo en el estado de México mediante sistemas de información geográfica y técnicas de regresión multivariantes: una aproximación a los procesos de deforestación. Investigaciones Geográficas 69:33-52.

PLADECO. 2010a. Plan de desarrollo comunal 2011-2014 de la comuna de Nueva Imperial. Región de La Araucanía. Chile. 155 pp.

PLADECO. 2010b. Plan de desarrollo comunal 2011-2014 Vilcún, actualización. Región de La Araucanía. Chile. 76 pp.

Pontius, R., E. Shusas, and M. Mceachern. 2004. Detecting important categorical land changes while accounting for persistence. Agriculture, Ecosystems \& Environment 101(2-3):251-68.

Schulz, J., L. Cayuela, C. Echeverria, J. Salas, and J. Rey. 2010. Monitoring land cover change of the dryland forest landscape of Central Chile (19752008). Applied Geography 30:436-447.

Stefanov, W., M. Ramsey, and P. Christiansen. 2001. Monitoring urban land cover change: an expert system approach to land cover classification of semiarid to arid urban centers. Remote Sensing of Environment 77:173-185.

Yuan, F., K. Sawaya, B. Loeffelholz, and M. Bauer. 2005. Land cover classification and change analysis of the Twin Cities (Minnesota) metropolitan area by multitemporal Landsat remote sensing. Remote Sensing of Environment 98(23):317-328. 